\title{
Sensitive and rapid detection of Zika virus by loop-mediated isothermal amplification
}

\author{
Jiangtao Zhao ${ }^{1} \cdot$ Ruo Feng $^{1}$ \\ Received: 12 April 2018 / Accepted: 3 November 2018 / Published online: 13 November 2018 \\ (c) Springer Science+Business Media, LLC, part of Springer Nature 2018
}

\begin{abstract}
Zika virus (ZIKV) is a mosquito-borne flavivirus, which is a pathogen affecting humans in Africa, Asia, and America. It is necessary to detect ZIKV with a rapid and sensitive molecular method to guide timely treatment. In this study, a loopmediated isothermal amplification (LAMP) assay was described, which is an attractive option as a fast, sensitive, and specific method for ZIKV detection using the NS5 protein coding region and the envelope protein (EP) coding region as target sequences. Two different techniques, a calcein/ $\mathrm{Mn}^{2+}$ complex chromogenic method and real-time turbidity monitoring, were employed. The specificity and sensitivity of the LAMP assay were determined. The assay's detection limit was $0.5 \times 10^{-9} \mathrm{pmol} / \mu \mathrm{l}$ DNA for NS5 protein coding region and $1.12 \times 10^{-11} \mathrm{pmol} / \mu \mathrm{l}$ DNA for E coding region, respectively, which is a 100-fold increase in sensitivity compared with real-time reverse transcription-polymerase chain reaction (RTPCR) and conventional PCR. All 12 non-ZIKA respiratory pathogens tested were negative for LAMP detection, indicating the high specificity of the primers for ZIKV. In conclusion, a visual detection LAMP assay was developed, which could be a useful tool for primary quarantine purposes and clinical screening, especially in situations where resources are poor and in point-of-care tests.
\end{abstract}

Keywords Zika virus $\cdot$ LAMP $\cdot$ Sensitivity $\cdot$ Specificity $\cdot$ Rapid detection

\section{Introduction}

Zika virus (ZIKV) is an emerging mosquito-borne arbovirus of the Flaviviridae family [1]. Zika virus has been reported as a pathogen of sporadic human infection for nearly half a century [2]. A widespread epidemic of ZIKV infections was found in Central and South America recently [3]. On February 1, 2016, the disease has been declared as a "Public Health Emergency of International Concern" by the World Health Organization (WHO) [2]. ZIKV is spread via mosquito transmission, sexual transmission, and vertical (mother to child) and blood transfusions [1]. The diagnosis of virus

\section{Edited by Joachim Jakob Bugert.}

Jiangtao Zhao

jtaozhao@163.com

$\triangle$ Ruo Feng

fr@zzu.edu.cn

1 Department of Histology and Embryology, School of Basic Medical Sciences, Zhengzhou University, Zhengzhou, People's Republic of China infection is typically performed by virus isolation, serological examinations, or specific antibodies from animals, but these methods are time consuming and not appropriate for clinical settings [4, 5]. In some virus laboratories, molecular-based diagnostic methods are employed using reverse transcription-PCR (RT-PCR), which takes several hours to obtain the results, which requires special equipment and skillful experiences [5, 6], and is complicated to perform in resource-limited laboratories in developing countries [7, 8]. Therefore, it is important to develop faster, more sensitive, and more accurate methods for timely diagnosis. LAMP is an emergency nucleic acid detection technique which was reported in 2000 and it performs high specificity as the amplification of DNA is conducted by two to three pairs of primer recognizing six independent regions on target gene [9]. LAMP was developed to amplify target DNA without any temperature change, which typically required denaturation, annealing, and extension. As the method could proceed at constant temperature with only a thermostat as the only equipment required, it is an ideal method for use in the field or in time-sensitive situations [9]. This technology has been widely used in clinical diagnosis; qualitative and quantitative 
detection of prevalent bacteria, viruses, and parasites; and fetal gender identification, etc. [7, 10]. Thus, LAMP could be a highly beneficial and convenient application to detect Zika virus due to its high specificity and stability, and it has been reported that LAMP shined a light on Zika virus [11-19].

The non-structural protein (NS5) and envelope protein (E) coding regions can be used as potential biomarkers for diagnostic purposes $[5,20]$. Our study is the first to use ZIKV NS5 and E genes as the target sequences in a LAMP assay. Here, we describe a visual method based on color change of the calcein/ $\mathrm{Mn}^{2+}$ mixture and LAMP results can be interpreted by naked eyes immediately. The purpose of this study was to develop a rapid and simple test of ZIKV detection based on LAMP technology, which requires only basic equipment and interprets results instantaneously through visual inspection.

\section{Materials and methods}

\section{Viruses and preparation of templates}

Thirteen genomes of respiratory pathogens including H1N1, H3N2, influenza A virus SWL, influenza B virus BV, influenza B virus BY, influenza A H7N9, human coronavirus HCoV-OC43, human coronavirus HCoV-NL63, human coronavirus HCoV-229E, SARS coronavirus, Dengue virus, Sudan EBOV (Subtype Sudan, strain Gulu), and the recombinant plasmids containing NS5 gene or E gene were used in this study (Table 1) [5, 20]. NS5 and E fragments were synthesized (Sangon Biotech Co., Ltd., Shanghai, China) and cloned into pBM21 vector to prepare the recombinant plasmids. RNA was extracted from viruses stocks using commercial QIAamp MinElute Virus Spin kit (Qiagen kit) according to the manufacturer's protocol. Reverse transcription was conducted according to standard procedure using M-MLV reverse transcriptase (Fermentas) according to the manufacturer's instruction. The DNA concentration was determined by measuring the optical density at $260 \mathrm{~nm}$ (OD260) and then dissolved in $20 \mu \mathrm{l}$ of DEPC-treated water and stored at $-80^{\circ} \mathrm{C}$ until use. All infectious materials were handled in biosafety level 3 facilities.

\section{Primer design}

The NS5 and E sequences of Zika virus strain Natal RGN were chosen as targets for the primers. The sequence with accession number KU527068 was retrieved and obtained from NCBI GenBank database, and was further analyzed by Primer Explorer Version 4 (http://primerexplorer.jp/elamp 4.0.0/index.html). Outer forward primer (F3), outer reverse primer (B3), forward inner primer (FIP), and reverse inner primer (BIP) were designed. Two additional loop primers (loop F and loop B) were designed to accelerate the amplification reaction. The FIP and BIP primers recognize both sense and antisense strands and were linked by a four-thymidine spacer (TTTT). PCR and RT-PCR were performed with the primers named PCR-F, PCR-R, RT-PCR-P, RTPCR-F, and RT-PCR-R. All the primers were synthesized commercially (Sangon Biotech Co., Ltd., Shanghai, China) (Tables 2, 3).

\section{LAMP reaction}

The LAMP reactions were carried out in a total volume of $25 \mu \mathrm{l}$ containing $12.5 \mu \mathrm{l}$ reaction mixture, $1 \mu \mathrm{l}$ Bst DNA polymerase, $2 \mu \mathrm{l}$ template by using the Loopamp DNA Amplification kit (Loopamp DNA Amplification Kit; Eiken Chemical Co., Ltd. Tochigi, Japan) for real-time turbidimeter and add another $1 \mu \mathrm{l}$ calcein solution (Eiken Chemical Co., Ltd.) for visual detection. An amount of 40 pmol was used for FIP
Table 1 Viruses used in this study

\begin{tabular}{lll}
\hline No. & Strain & Source \\
\hline 1 & H1N1 & Our microorganism center \\
2 & H3N2 & Our microorganism center \\
3 & Influenza A virus SWL & Our microorganism center \\
4 & Influenza B virus BV & Our microorganism center \\
5 & Influenza B virus BY & Our microorganism center \\
6 & Influenza A H7N9 & Our microorganism center \\
7 & Human coronavirus HCoV-OC43 & Our microorganism center \\
8 & Human coronavirus HCoV-NL63 & Our microorganism center \\
9 & Human coronavirus HCoV-229E & Our microorganism center \\
10 & SARS coronavirus & Our microorganism center \\
11 & Dengue virus & Our microorganism center \\
12 & Sudan EBOV (Subtype Sudan, strain Gulu) & Our microorganism center \\
13 & ZIKV strain Natal RGN & Our microorganism center \\
\hline
\end{tabular}


Table 2 Primers used for the specific amplification of ZIKV NS5 gene
Table 3 Primers used for the specific amplification of ZIKV EP gene

\begin{tabular}{lll}
\hline Primer & Type & Sequence $\left(5^{\prime}-3^{\prime}\right)$ \\
\hline Zika2(NS5)-Natal2-F3 & Forward outer & ggtccattgtggttcctg \\
Zika2(NS5)-Natal2-B3 & Backward outer & tcaactggcacagatgaaca \\
Zika2(NS5)-Natal2-FIP & Forward inner & agtctcceggatgctccatcctttccgccaccaagatgaactg \\
Zika2(NS5)-Natal2-BIP & Backward inner & tcatatgcgcaaatgtggcagctttcattggccatcagtcggag \\
Zika2(NS5-Natal2)-LF & Loop forward & agagacgcgggcccggc \\
Zika2(NS5-Natal2)-LB & Loop backward & tttattccacagaagg \\
Zika(NS5)-PCR-F & PCR forward & atgtcctagaagagatgag \\
Zika(NS5)-PCR-R & PCR backward & tctccetttccatgga \\
Zika(NS5)-qRT-PCR-probe & RT-PCR probe & (FAM)ct(c/t)agaccagctgaa(a/g)(BHQ1) \\
Zika(NS5)-qRT-PCR-probe & RT-PCR forward & aa(a/g)tacacatacca(a/g)aacaaagtggt \\
Zika(NS5)-qRT-PCR-probe & RT-PCR backward & tcc(a/g)ctccc(c/t)ct(c/t)tggtcttg \\
\hline
\end{tabular}

FAM 6-carboxyfluorescein; BHQ1 Black Hole Quencher 1

\begin{tabular}{lll}
\hline Primer & Type & Sequence $\left(5^{\prime}-3^{\prime}\right)$ \\
\hline Zika-1-F3 & Forward outer & tccaccatttggggactctt \\
Zika-1-B3 & Backward outer & gatgccettgcccaatga \\
Zika-1-FIP & Forward inner & caatggtgctgccactcctgtgtttattgtcataggagtcgggga \\
Zika-1-BIP & Backward inner & ttgaagccactgtgagaggtgctttgcctccaactgatccaaagt \\
Zika-1-LF & Loop forward & cagtggtgggtgatcttc \\
Zika-1-LB & Loop backward & gagaatggcagtcttgg \\
Zika(EP)-PCR-F & PCR forward & ataaccgctaacccegtaatcact \\
Zika(EP)-PCR-R & PCR backward & ctcccctaaggccaagcacataa \\
Zika(EP)-qRT-PCR-Probe & RT-PCR probe & (FAM)cataggagtcggggag(BHQ1) \\
Zika(EP)-qRT-PCR-F & RT-PCR forward & tccaccatttggggactctt \\
Zika(EP)-qRT-PCR-R & RT-PCR backward & gatgccttgcccaatga \\
\hline
\end{tabular}

FAM 6-carboxyfluorescein; BHQ1 Black Hole Quencher 1 and BIP; a concentration of 20 pmol was used for LB and LF; and a concentration of 5 pmol was used for F3 and B3. Finally, the appropriate amount of template genome is added to the reaction tube. The reaction mix was overlaid with the wax to prevent cross-contamination of samples by aerosol and carried out in the reaction tubes (Eiken Chemical Co. Ltd.) for $60 \mathrm{~min}$ at $65^{\circ} \mathrm{C}$. During the amplification process, the wax melted into a liquid without interfering with the reaction, and the wax solidified as the temperature in the tube fell to room temperature.

Two different detection methods based on sample turbidity and fluorescence were used to detect the LAMP products. Spectrophotometric analysis was performed by recording optical density $(650 \mathrm{~nm})$ using a Loopamp realtime turbidimeter (LA-320C; Eiken Chemical Co., Ltd.), and real-time changes in turbidity were monitored every $6 \mathrm{~s}$. For direct visual detection, $1 \mu \mathrm{l}$ of calcein fluorescence detection reagent was added to $25 \mu \mathrm{l}$ of LAMP product. As the magnesium ions form a complex with calcein, LAMP amplification produces a green fluorescence emission. For negative reactions, the color is still orange, but for positive reactions, the color changes from orange to green. It can be observed under natural light or with the naked eye under 365 nm UV light [21].

\section{One-step E real-time rRT-PCR}

To describe the sensitivity of LAMP detection, a one-step E rRT-PCR assay capable of detecting ZIKV NS5 and E sequences was used with $25 \mu \mathrm{l}$ reaction mix under the following conditions: $2 \mu \mathrm{l}$ of $5 \mu \mathrm{M}$ of Probe, $1 \mu \mathrm{l}$ of $5 \mu \mathrm{M}$ of each primer, $12.5 \mu \mathrm{l}$ of $2 \times$ Pre Mix Ex Taq, $7.5 \mu \mathrm{l}$ of DNA/ RNA free water, and $1 \mu$ of the DNA specimens. The negative control consisted of water and twelve genomes of respiratory pathogens. The following thermal profile was initially carried out at $94{ }^{\circ} \mathrm{C}$ for $5 \mathrm{~min}$; amplification, 35 cycles of $94{ }^{\circ} \mathrm{C}$ for $30 \mathrm{~s}, 55^{\circ} \mathrm{C}$ for $30 \mathrm{~s}$, and $72{ }^{\circ} \mathrm{C}$ for $45 \mathrm{~s}$; final extension, $72{ }^{\circ} \mathrm{C}$ for $7 \mathrm{~min}$. The data were analyzed using the SDS software from Applied Biosystems [5]. 


\section{PCR detection}

PCRs were carried out with $25 \mu$ reaction mixtures that contained the following components: $12.5 \mu \mathrm{l}$ of PCR Master Mix reagents (Tiangen Biotech Co., Ltd. Beijing, China), $9.5 \mu \mathrm{l}$ of double-distilled water, $1 \mu \mathrm{l}$ of $5 \mu \mathrm{M}$ of each primer, and $1 \mu \mathrm{l}$ of DNA template as was used in the LAMP reaction. The reaction was initially carried out at $95{ }^{\circ} \mathrm{C}$ for $5 \mathrm{~min}$; amplification, 30 cycles of $95{ }^{\circ} \mathrm{C}$ for $30 \mathrm{~s}, 55^{\circ} \mathrm{C}$ for $30 \mathrm{~s}$, and $72{ }^{\circ} \mathrm{C}$ for $50 \mathrm{~s}$; final extension, $72{ }^{\circ} \mathrm{C}$ for $5 \mathrm{~min}$. The PCR-amplified products were separated with $1 \%$ agarose gel (Amresco) electrophoresis and stained with GelRed. Images were documented with a Gel Doc EQ imaging system (Bio-Rad).

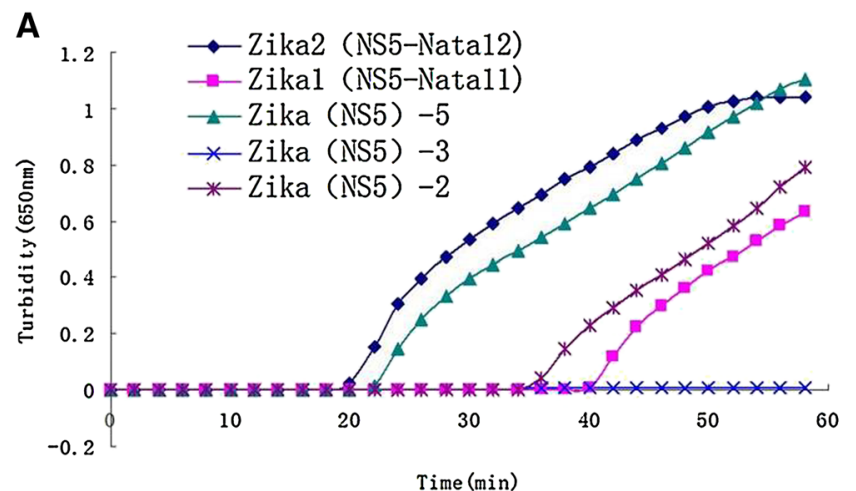

Fig. 1 The most appropriate primers for the loop-mediated isothermal amplification assay. a A total of five sets of primers including Zika(NS5)-2, Zika(NS5)-3, Zika(NS5)-5, Zika1(NS5-Natal1), and Zika2(NS5-Natal2) were designed to detect the recombinant plasmid containing NS5 gene. b A total of three sets of primers includ-

\section{Results}

\section{Optimization of LAMP assay}

Five and three sets of primers were initially tested to detect ZIKV NS5 gene and E gene under the same reaction conditions, respectively. The "Zika 2 (NS5-Nata12)" primer set for NS5 gene and the "Zika-1" primer set for E gene began to amplify the target genes in the shortest time, respectively (Fig. 1a, b). Thus they were chosen as the optimal primer sets for ZIKV NS5 gene and E gene detection with LAMP (Table 2).

To optimize the reaction temperatures of the primers in the LAMP reaction, temperatures from 55 to $69{ }^{\circ} \mathrm{C}$ at $2{ }^{\circ} \mathrm{C}$ intervals were compared for optimal amplification. As shown in Fig. 2a, b, the most suitable reaction temperature range was $61-67^{\circ} \mathrm{C}$. Finally, we chose $65^{\circ} \mathrm{C}$ as the optimal reaction temperature.

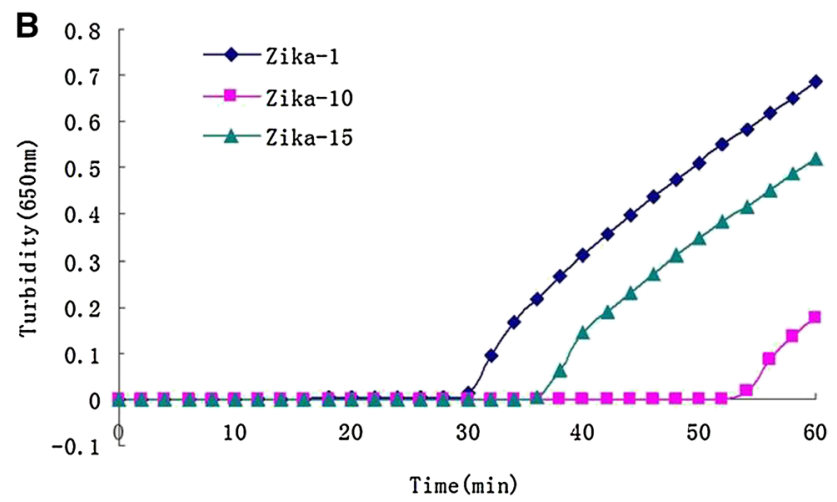

ing Zika-1, Zika-10, and Zika-15 were designed to detect the recombinant plasmid containing $\mathrm{E}$ gene. Turbidity was monitored and recorded every $6 \mathrm{~s}$ for five sets of primers used to amplify the target gene with a Loopamp Real-time Turbidimeter at $650 \mathrm{~nm}$
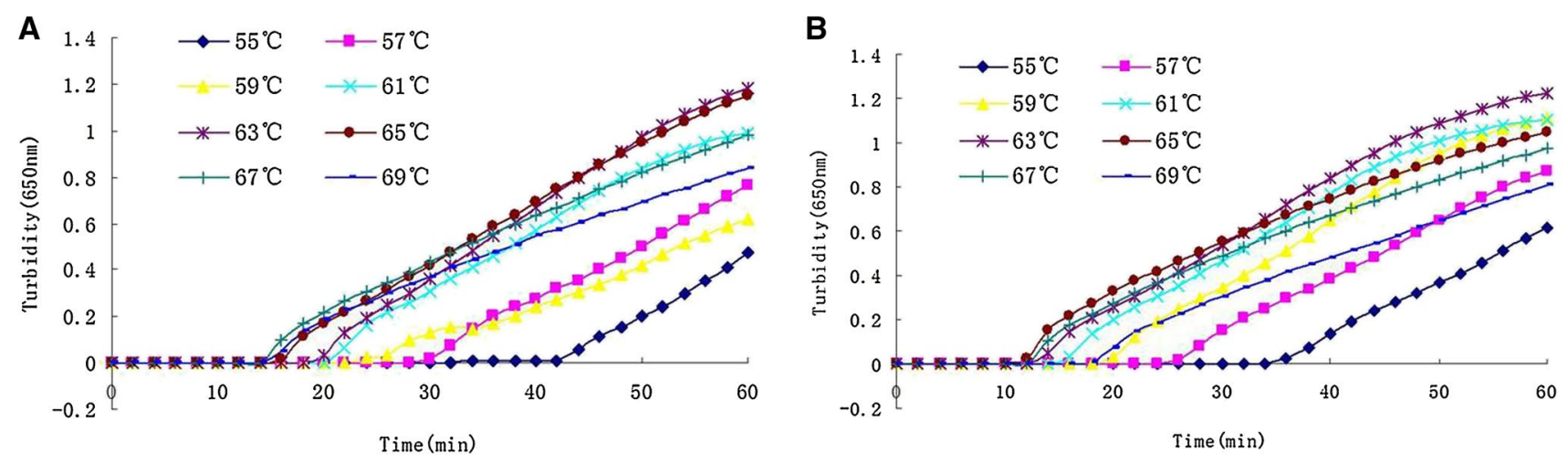

Fig. 2 The most appropriate reaction temperatures for the loop-mediated isothermal amplification assay for NS5 (a) and E (b). Reaction temperatures ranged from 55 to $69^{\circ} \mathrm{C}$ with $2{ }^{\circ} \mathrm{C}$ intervals. Turbidity was monitored every $6 \mathrm{~s}$ with a Loopamp Real-time Turbidimeter at $650 \mathrm{~nm}$ 


\section{Specificity of the LAMP assay}

To test the LAMP specificity for NS5 gene and E gene, we tested 12 non-Zika virus in addition to the recombinant plasmids containing NS5 gene or E gene as the positive control. Figure 3 shows that the recombinant plasmids containing NS5 gene or E gene were identified positively by LAMP using turbidity monitoring (Fig. 3a, c) and visual observation (Fig. 3b, d). Figure 3a, b shows the results of NS5 gene detection and Fig. 3c, d shows the results of E gene detection. All non-Zika virus tested negative, including the blank control, indicating that the LAMP method was specific for ZIKV.

\section{Sensitivity of the LAMP assay vs. PCR and qRT-PCR for ZIKV NS5 and E genes}

To determine the sensitivity of the LAMP assay for ZIKV, a series of dilutions of the recombinant plasmids containing NS5 gene or E gene were prepared. The times of positivity detection ranged from $18 \mathrm{~min}$ for $0.5 \times 10^{-4} \mathrm{pmol} / \mu \mathrm{l}$ to $40 \mathrm{~min}$ for $0.5 \times 10^{-9} \mathrm{pmol} / \mu \mathrm{l}$ of the recombinant plasmid containing NS5 gene by real-time monitoring (Fig. 4a) and the times of positivity detection ranged from $16 \mathrm{~min}$ for $1.12 \times 10^{-6} \mathrm{pmol} / \mu \mathrm{l}$ to $30 \mathrm{~min}$ for $1.12 \times 10^{-11} \mathrm{pmol} /$ $\mu \mathrm{l}$ of the recombinant plasmid containing $\mathrm{E}$ gene by realtime monitoring (Fig. 4d). Thus, the LAMP detection limit for NS5 gene is $0.5 \times 10^{-9} \mathrm{pmol} / \mu \mathrm{l}$ of the recombinant
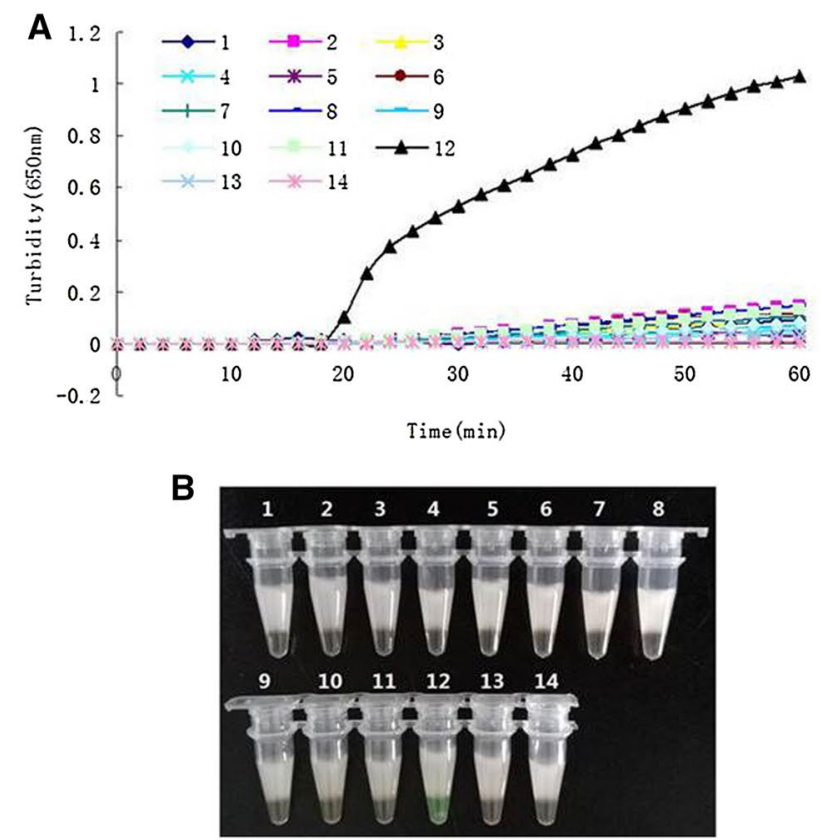

Fig. 3 Specificity of ZIKV NS5 (a, b) and E (c, d) detection by LAMP. a, c Turbidity was monitored every $6 \mathrm{~s}$ with a Loopamp Real-time Turbidimeter at $650 \mathrm{~nm}$. b, d Visual detection using a calcein fluorescent detection reagent. Lane 1, H1N1; 2, H3N2; 3, SWL; plasmids containing NS5 gene in a $65^{\circ} \mathrm{C}$ reaction lasting for $40 \mathrm{~min}$, and the LAMP detection limit for $E$ gene is $1.12 \times 10^{-11} \mathrm{pmol} / \mu \mathrm{l}$ of the recombinant plasmids containing $\mathrm{E}$ gene in a $65^{\circ} \mathrm{C}$ reaction lasting for $30 \mathrm{~min}$. For the visual inspection, all positive reactions changed to green while negative ones remained orange under natural or $365 \mathrm{~nm}$ UV light (Fig. 4b, e). These data indicate that the sensitivity of the two detection methods was the same. For comparison, real-time RT-PCR and PCR were performed. The detection limit of real-time RT-PCR for NS5 gene was $0.5 \times 10^{-7} \mathrm{pmol} / \mu \mathrm{l}$ and was achieved with a higher $C_{\mathrm{t}}$ value $\left(C_{\mathrm{t}}=31.68 \pm 0.983\right)$ (Table 4$)$. The detection limit of PCR for NS5 gene was also $0.5 \times 10^{-7} \mathrm{pmol} / \mu \mathrm{l}$ (Fig. 4c). The detection limit of real-time RT-PCR for $E$ gene was $1.12 \times 10^{-9} \mathrm{pmol} / \mu \mathrm{l}$ and was achieved with a higher $C_{\mathrm{t}}$ value $\left(C_{\mathrm{t}}=32.75 \pm 0.085\right)$ (Table 5). The detection limit of PCR for $E$ gene was also $1.12 \times 10^{-9} \mathrm{pmol} / \mu \mathrm{l}$ (Fig. 4f). Therefore, we conclude that LAMP assay is more sensitive to ZIKV than real-time RT-PCR.

\section{Discussion}

ZIKV infection is characterized by mild disease associated with fever, headache, rash, joint pain, and conjunctivitis, and there are special reports related to Guillain-Barré syndrome (GBS) and microcephaly [22]. Therefore, rapid and sensitive laboratory diagnostic tests are highly desirable.
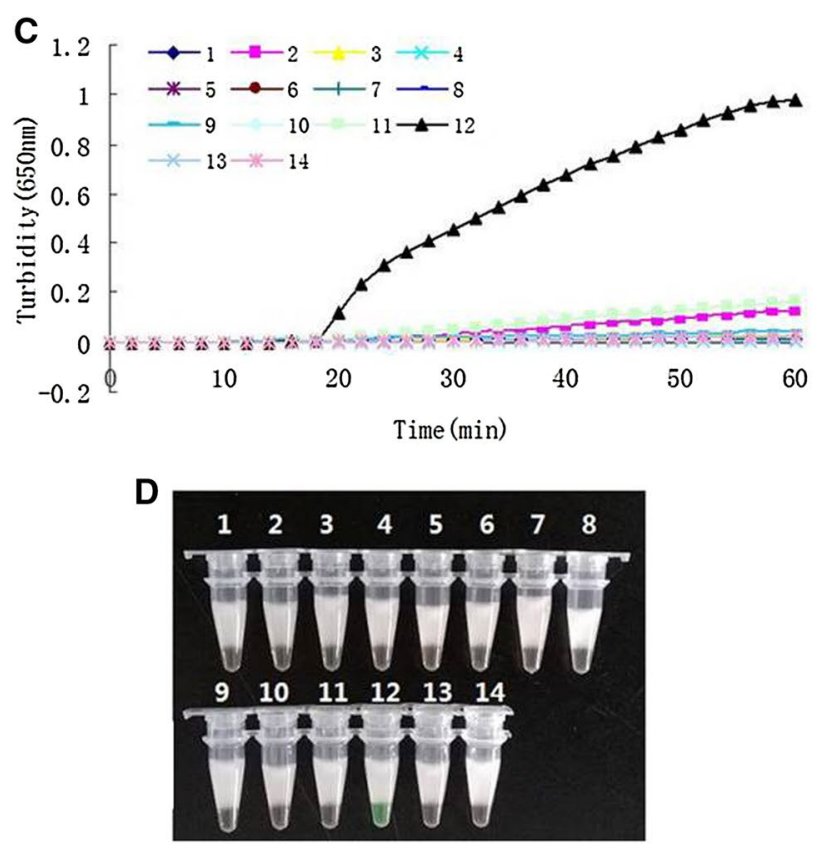

4, BV; 5, BY; 6, H7N9; 7, OC43; 8, NL63; 9, 229E; 10, SARS; 11, Dengue; 12, positive control (the recombinant plasmids containing NS5 gene or E gene); 13, Ebola; 14, negative control (double-distilled water) 

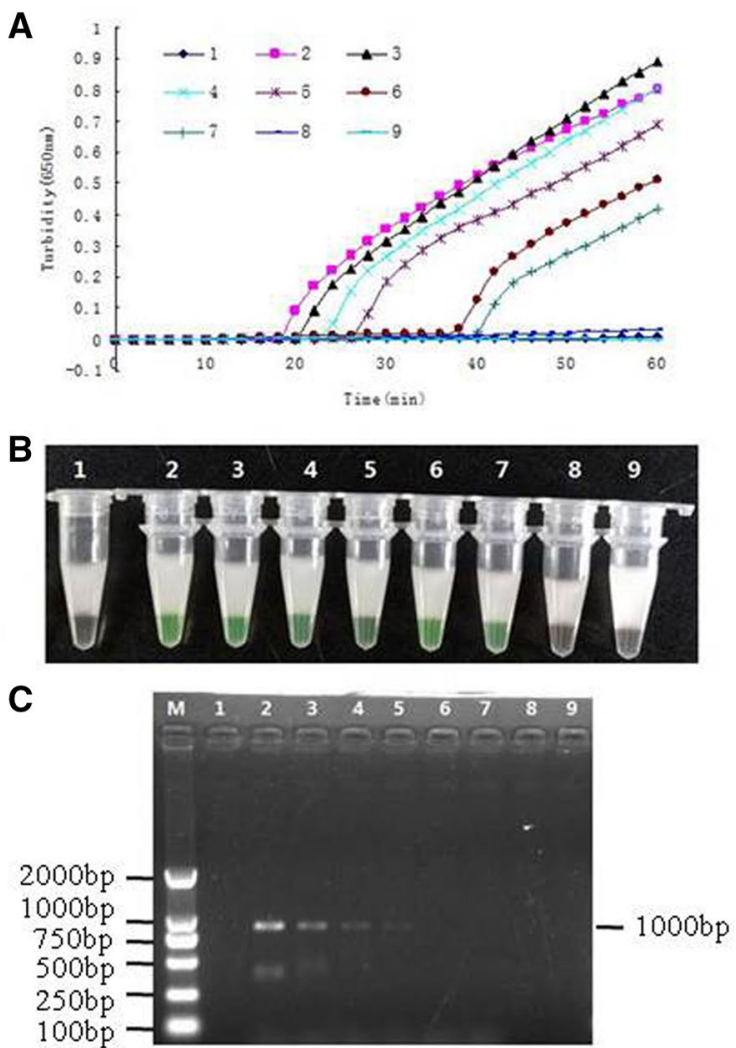

Fig. 4 Comparison of the sensitivities of the LAMP reaction and conventional PCR in detecting the ZIKV NS5 gene (a-c). a Turbidity monitoring, $\mathbf{b}$ visual detection, $\mathbf{c}$ PCR detection. The recombinant plasmid containing NS5 gene was serially diluted 10-fold from $0.5 \times 10^{-2}$ to $0.5 \times 10^{-9} \mathrm{pmol} / \mu \mathrm{l}$. 1 , negative control (doubledistilled water); $2,0.5 \times 10^{-2} \mathrm{pmol} / \mu \mathrm{l} ; 3,0.5 \times 10^{-3} \mathrm{pmol} / \mu \mathrm{l} ; 4$, $0.5 \times 10^{-4} \mathrm{pmol} / \mu \mathrm{l} ; 5,0.5 \times 10^{-5} \mathrm{pmol} / \mu \mathrm{l} ; 6,0.5 \times 10^{-6} \mathrm{pmol} / \mu \mathrm{l} ; 7$, $0.5 \times 10^{-7} \mathrm{pmol} / \mu \mathrm{l} ; 8,0.5 \times 10^{-8} \mathrm{pmol} / \mu \mathrm{l} ; 9,0.5 \times 10^{-9} \mathrm{pmol} / \mu \mathrm{l}$. Com-

Table 4 Detection limit of the qRT-PCR assay of ZIKV NS5 gene

\begin{tabular}{llll}
\hline $\begin{array}{l}\text { Synthetic DNA } \\
\text { pmol/ } \mu \mathrm{l}\end{array}$ & $\begin{array}{l}\text { Nb positive/nb } \\
\text { tested }\end{array}$ & $C_{\mathrm{t}}$ & Percentage \\
\hline $0.5 \times 10^{-2}$ & $3 / 3$ & $11.12 \pm 0.068$ & 100 \\
$0.5 \times 10^{-3}$ & $3 / 3$ & $15.38 \pm 0.084$ & 100 \\
$0.5 \times 10^{-4}$ & $3 / 3$ & $19.71 \pm 0.125$ & 100 \\
$0.5 \times 10^{-5}$ & $3 / 3$ & $23.34 \pm 0.256$ & 100 \\
$0.5 \times 10^{-6}$ & $3 / 3$ & $27.27 \pm 0.214$ & 100 \\
$0.5 \times 10^{-7}$ & $3 / 3$ & $31.68 \pm 0.983$ & 100 \\
$0.5 \times 10^{-8}$ & $0 / 3$ & $\mathrm{Neg}$ & 0 \\
$0.5 \times 10^{-9}$ & $0 / 3$ & $\mathrm{Neg}$ & 0 \\
$0.5 \times 10^{-10}$ & $0 / 3$ & $\mathrm{Neg}$ & 0 \\
$0.5 \times 10^{-11}$ & $0 / 3$ & $\mathrm{Neg}$ & 0 \\
\hline
\end{tabular}

ZIKV's diagnostic tests have traditionally been accomplished through time-consuming methods of cultivation. The present study approved the LAMP assay to directly detect

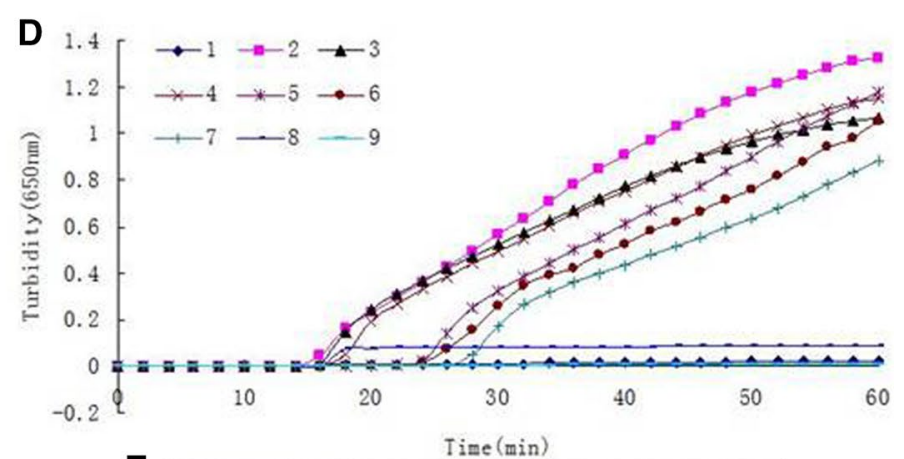

E

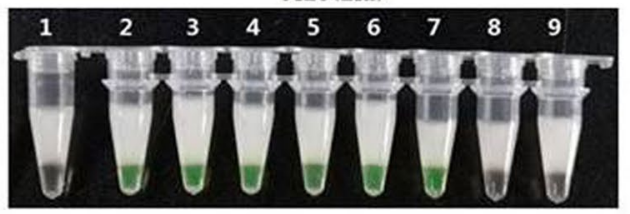

$\mathbf{F}$

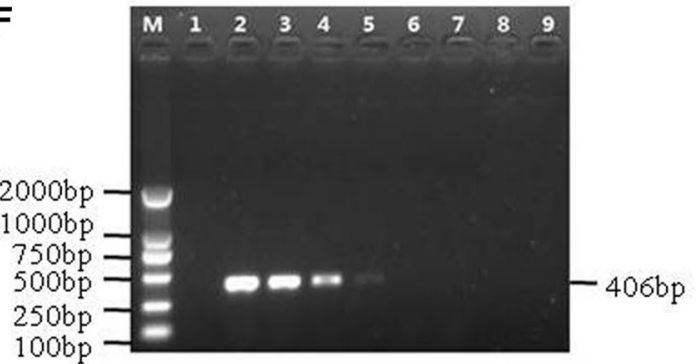

parison of the sensitivities of the LAMP reaction and conventional PCR in detecting the ZIKV E gene (d-f). $\mathbf{d}$ Turbidity monitoring, $\mathbf{e}$ visual detection, $\mathbf{f}$ PCR detection. The recombinant plasmid containing E gene was serially diluted 10 -fold from $1.12 \times 10^{-4} \mathrm{pmol} / \mu \mathrm{l}$ to $1.12 \times 10^{-11} \mathrm{pmol} / \mu \mathrm{l} .1$, negative control (double-distilled water); 2 , $1.12 \times 10^{-4} \mathrm{pmol} / \mu \mathrm{l} ; 3,1.12 \times 10^{-5} \mathrm{pmol} / \mu \mathrm{l} ; 4,1.12 \times 10^{-6} \mathrm{pmol} / \mu \mathrm{l} ; 5$, $1.12 \times 10^{-7} \mathrm{pmol} / \mathrm{\mu l} ; 6,1.12 \times 10^{-8} \mathrm{pmol} / \mathrm{\mu l} ; 7,1.12 \times 10^{-9} \mathrm{pmol} / \mu \mathrm{l} ; 8$, $1.12 \times 10^{-10} \mathrm{pmol} / \mu \mathrm{l} ; 9,1.12 \times 10^{-11} \mathrm{pmol} / \mu \mathrm{l}$

Table 5 Detection limit of the qRT-PCR assay for ZIKV EP gene

\begin{tabular}{llll}
\hline Synthetic DNA pmol/ul & $\begin{array}{l}\mathrm{Nb} \\
\text { positive/nb } \\
\text { tested }\end{array}$ & $C_{\mathrm{t}}$ & Percentage \\
\hline $1.12 \times 10^{-2}$ & $3 / 3$ & $09.22 \pm 0.071$ & 100 \\
$1.12 \times 10^{-3}$ & $3 / 3$ & $13.75 \pm 0.072$ & 100 \\
$1.12 \times 10^{-4}$ & $3 / 3$ & $16.83 \pm 0.031$ & 100 \\
$1.12 \times 10^{-5}$ & $3 / 3$ & $20.73 \pm 0.108$ & 100 \\
$1.12 \times 10^{-6}$ & $3 / 3$ & $23.46 \pm 0.329$ & 100 \\
$1.12 \times 10^{-7}$ & $3 / 3$ & $26.36 \pm 0.039$ & 100 \\
$1.12 \times 10^{-8}$ & $3 / 3$ & $29.86 \pm 0.176$ & 100 \\
$1.12 \times 10^{-9}$ & $3 / 3$ & $32.75 \pm 0.085$ & 100 \\
$1.12 \times 10^{-10}$ & $0 / 3$ & Neg & 0 \\
$1.12 \times 10^{-11}$ & $0 / 3$ & Neg & 0 \\
$1.12 \times 10^{-12}$ & $0 / 3$ & Neg & 0 \\
$1.12 \times 10^{-13}$ & $0 / 3$ & Neg & 0 \\
\hline
\end{tabular}


the NS5 and E gene to aid in the diagnosis of ZIKV. And a mass of reports proved LAMP had more sensitivity and specificity for detecting pathogen [23].

Here, we described a visual LAMP method for detecting NS5 and E gene of ZIKV. Detection of specificity was performed here using 13 viruses including 12 of other species and the recombinant plasmid containing NS5 or E gene by real-time turbidimeter and visual methods, respectively, and with the recombinant plasmid containing NS5 or E gene being positive and all the other 12 species being negative. These results not only stated that the visual LAMP method has the same specificity with using real-time turbidimeter but also had specificity for detecting ZIKV specific genes. Furthermore, we compared the ability of LAMP to detect NS5 and E sensitivity using 10-fold serial dilution of the recombinant plasmid containing NS5 or E gene with that of traditional PCR method and RT-PCR method. The detection limit of LAMP assay was 100-fold lower than the value of PCR and RT-PCR. More than that, LAMP can finish in 40 min with a simple thermostat. Therefore, LAMP posses more rapid and more simple character and these features make LAMP assay more suitable for field and/or time purpose.

There are various advantages of LAMP assay but it has a relatively high rate of false-positive results. For the reason that the amplification efficiency of the LAMP assay is extremely high and $20 \mu \mathrm{g}$ of specific DNA can be synthesized in a $25-\mu l$ reaction mixture within $60 \mathrm{~min}$ [24], it was very necessary to separate the reagent preparation and the performance of the test to avoiding contamination. In our study, a low-melting point wax was added to the reaction tube to prevent the spread of the amplification products. It seems to work well to avoiding contamination.

In conclusion, the visual LAMP assay developed here for detecting ZIKV is more sensitive than PCR and RT-PCR and the results can be observed by naked eyes immediately when amplification is completed. For sensitive and specificity, the results of this visual method were consistent with real-time turbidimeter observations. Consequently, a specific, sensitive, rapid, and cost-effective means for ZIKV detection with LAMP method was established. It is very helpful for primary health care units to use the LAMP assay to detect ZIKV.

Acknowledgements This work received support from National Natural Science Foundation of China Grant (81401995).

Author contributions JZ and RF performed the research, analyzed the data, and wrote the paper.

\section{Compliance with ethical standards}

Conflict of interest All authors declare that they have no conflicts of interest.

\section{References}

1. Eppes C, Rac M, Dunn J, Versalovic J, Murray KO, Suter MA, Sanz Cortes M, Espinoza J, Seferovic MD, Lee W, Hotez P, Mastrobattista J, Clark SL, Belfort MA, Aagaard KM (2017) Testing for Zika virus (ZIKV) infection in pregnancy: key concepts to deal with an emerging epidemic. Am J Obstet Gynecol 213(3):209225. https://doi.org/10.1016/j.ajog.2017.01.020

2. Sakkas H, Economou V, Papadopoulou C (2016) Zika virus infection: past and present of another emerging vector-borne disease. $\mathrm{J}$ Vector Borne Dis 53:305-311

3. Zhang ZW, Li ZL, Yuan S (2016) The role of secretory autophagy in Zika virus transfer through the placental barrier. Front Cell Infect Microbiol 6:206. https://doi.org/10.3389/fcimb.2016.00206

4. Okafuji T, Yoshida N, Fujino M, Motegi Y, Ihara T, Ota Y, Notomi T, Nakayama T (2005) Rapid diagnostic method for detection of mumps virus genome by loop-mediated isothermal amplification. J Clin Microbiol 43:1625-1631. https://doi.org/10.1128/ JCM.43.4.1625-1631.2005

5. Faye O, Diallo D, Diallo M, Weidmann M, Sall AA (2013) Quantitative real-time PCR detection of Zika virus and evaluation with field-caught mosquitoes. Virol J 10:311. https://doi. org/10.1186/1743-422X-10-311

6. Kashiwagi Y, Kawashima H, Takekuma K, Hoshika A, Mori T, Nakayama T (1997) Detection of mumps virus genome directly from clinical samples and a simple method for genetic differentiation of the Hoshino vaccine strain from wild strains of mumps virus. J Med Virol 52:195-199

7. Zhao X, He X, Li H, Zhao J, Huang S, Liu W, Wei X, Ding Y, Wang Z, Zou D, Wang X, Dong D, Yang Z, Yan X, Huang L, Du $S$, Yuan J (2015) Detection of streptococcus pyogenes using rapid visual molecular assay. FEMS Microbiol Lett 362:fnv148. https:// doi.org/10.1093/femsle/fnv148

8. Xu MY, Liu SQ, Deng CL, Zhang QY, Zhang B (2016) Detection of Zika virus by SYBR green one-step real-time RT-PCR. J Virol Methods 236:93-97. https://doi.org/10.1016/j.jviro met.2016.07.014

9. Notomi T, Okayama H, Masubuchi H, Yonekawa T, Watanabe K, Amino N, Hase T (2000) Loop-mediated isothermal amplification of DNA. Nucleic Acids Res 28:e63

10. Chotiwan N, Brewster CD, Magalhaes T, Weger-Lucarelli J, Duggal NK, Ruckert C, Nguyen C, Garcia Luna SM, Fauver JR, Andre B, Gray M, Black WCt, Kading RC, Ebel GD, Kuan G, Balmaseda A, Jaenisch T, Marques ETA, Brault AC, Harris E, Foy BD, Quackenbush SL, Perera R, Rovnak (2017) Rapid and specific detection of Asian- and African-lineage Zika viruses. J Sci Transl Med. https://doi.org/10.1126/scitranslmed.aag0538

11. Brewster CD, Chotiwan N, Perera R, Quackenbush SL, Rovnak J (2018) LAMP assays of Zika virus and other infectious agents will inevitably see expanded use due to their simplicity, sensitivity, specificity, and economy. Ann Transl Med 6(10):196. https:// doi.org/10.21037/atm.2018.03.01

12. Calvert AE, Biggerstaff BJ, Tanner NA, Lauterbach M, Lanciotti RS (2017) Rapid colorimetric detection of Zika virus from serum and urine specimens by reverse transcription loop-mediated isothermal amplification (RT-LAMP). PLoS ONE 12:e0185340. https://doi.org/10.1371/journal.pone.0185340

13. Castro T, Sabalza M, Barber C, Abrams W, Da Costa AC, De Padua Milagres FA, Braz-Silva PH, Malamud D, Gallottini M (2018) Rapid diagnosis of zika virus through saliva and urine by loop-mediated isothermal amplification (LAMP). J Oral Microbiol 10:1510712. https://doi.org/10.1080/20002297.2018.1510712

14. Guo XG, Zhou YZ, Li Q, Wang W, Wen JZ, Zheng L, Wang Q (2018) Rapid and reliable diagnostic method to detect Zika virus by real-time fluorescence reverse transcription loop-mediated 
isothermal amplification. AMB Express 8(1):60. https://doi. org/10.1186/s13568-018-0591-6

15. Kaarj K, Akarapipad P, Yoon JY (2018) Simpler, faster, and sensitive zika virus assay using smartphone detection of loop-mediated isothermal amplification on paper microfluidic chips. Sci Rep 8:12438. https://doi.org/10.1038/s41598-018-30797-9

16. Kurosaki Y, Martins DBG, Kimura M, Catena ADS, Borba M, Mattos SDS, Abe H, Yoshikawa R, de Lima Filho JL, Yasuda J (2017) Development and evaluation of a rapid molecular diagnostic test for Zika virus infection by reverse transcription loopmediated isothermal amplification. Sci Rep 7(1):13503. https:// doi.org/10.1038/s41598-017-13836-9

17. Lamb LE, Bartolone SN, Tree MO, Conway MJ, Rossignol J, Smith CP, Chancellor MB (2018) Rapid detection of zika virus in urine samples and infected mosquitos by reverse transcriptionloop-mediated isothermal amplification. Sci Rep 8(1):3803. https ://doi.org/10.1038/s41598-018-22102-5

18. Lustig Y, Sofer D, Hindiyeh M, Mendelson E (2018) LAMP assay for specific detection of Asian and African lineage zika virus: will it meet the expectations. Ann Transl Med 6:53. https://doi. org/10.21037/atm.2017.11.25

19. Smith OM (2017) LAMP shines a light on zika virus. Science 356:497-498. https://doi.org/10.1126/science.356.6337.497-g
20. Faye O, Dupressoir A, Weidmann M, Ndiaye M, Alpha Sall A (2008) One-step RT-PCR for detection of zika virus. J Clin Virol 43:96-101. https://doi.org/10.1016/j.jcv.2008.05.005

21. Tomita N, Mori Y, Kanda H, Notomi T (2008) Loop-mediated isothermal amplification (LAMP) of gene sequences and simple visual detection of products. Nat Protoc 3:877-882. https://doi. org/10.1038/nprot.2008.57

22. Saiz JC, Vazquez-Calvo A, Blazquez AB, Merino-Ramos T, Escribano-Romero E, Martin-Acebes MA (2016) Zika virus: the latest newcomer. Front Microbiol 7:496. https://doi.org/10.3389/ fmicb.2016.00496

23. Kim DW, Kilgore PE, Kim EJ, Kim SA, Anh DD, Dong BQ, Kim JS, Seki M (2012) The enhanced pneumococcal LAMP assay: a clinical tool for the diagnosis of meningitis due to Streptococcus pneumoniae. PLoS ONE 7:e42954. https://doi.org/10.1371/journ al.pone.0042954

24. Mori Y, Nagamine K, Tomita N, Notomi T (2001) Detection of loop-mediated isothermal amplification reaction by turbidity derived from magnesium pyrophosphate formation. Biochem Biophys Res Commun 289:150-154. https://doi.org/10.1006/ bbrc.2001.5921 